\title{
チャ葉からの葉肉細胞，表皮組織 及び維管束組織の分離法
}

\author{
静岡大学農学部 \\ 久保井 徹・寺尾玲子 \\ (平成 5 年 7 月 12 日受理)

\section{Isolation of Mesophyll Cells, Epidermis and Vascular Tissues from Tea Leaves}

\author{
Toru KUBOI and Reiko TERAO \\ Faculty of Agriculture, Shizuoka University
}

\begin{abstract}
A method for isolating palisade and spongy parenchyma, upper and lower epidermis, and vascular tissues from tea leaves was established. Leaf pieces were incubated with a hypertonic medium containing Macerozyme and Pectolyase at room temperature for $1 \mathrm{hr}$ (young leaves) to $10 \mathrm{hr}$ (old leaves). The leaf pieces were separated into upper and lower epidermis and vascular tissues. Mesophyll cells adhered to these tissues were released by soft brushing: Palisade and spongy cells were isolated from upper epidermis and the other two parts, respectively. Most of the isolated cells were morphologically intact. Based on $1 \mathrm{~g}$ of fresh leaf, mean number of cells contained in the fractions of upper and lower epidermis, and palisade and spongy cells were $10,9,5,23$ and 26 millions, respectively. Purity of the palisade and spongy fractions were $90-98 \%$. The epidermal fractions were practically pure. Concerning to the vascular fraction, bundle sheath cells could not be distin-guished from mesophyll cells contaminated to this fraction. The estimated number of chloroplast containing cells in the vascular fraction was $8 \cdot 10^{6} / \mathrm{g}$.
\end{abstract}

\section{1. 緒言}

チャ (Camellia sinensis (L.) O. KUNTZE) 葉内における成分や酵素の局在性を調べるこ とは, チャの品質を向上させ, また生理機能 を理解する上で重要である。これまでに, 組 織化学的方法によって全カテキンやポリフェ ノールオキシダーゼの局在性が検討された 例"はあるものの，カテキン類や各種アミノ 酸などの葉組織内分布を分子種毎に測定する ことは不可能であった。

葉組織を葉肉細胞, 表皮組織及び維管束組 織に分離できれば，それぞれを分析すること が可能になる。酵素的にさく状組織と海綿状 組織の細胞を分離する方法は夕バゴで報告
されて以来, いくつかの植物では行われてい るが，チャのように表皮をはがしにくい植物 では極めて困難とされていた。しかしながら， 適当な条件で細胞間に存在する多糖類の分解 酵素を作用させることにより, 組織の分離は 行えるはずである。青木 ${ }^{3}$ は葉を細断後, 酵素 的に葉肉細胞を単離してその光合成能を測定 しており，また著者ら ${ }^{4} は$ はナのプロトプラ ストを得る過程で表皮組織を酵素処理によっ て除去しているからである。

そこで, チャ葉を構成する各組織を, 酵素 処理によって分離する方法を検討した。

\section{2. 材料と方法}

\section{1 植物材料}

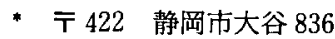


保温ガラス室内で水耕栽培らした‘やぶき た’の若葉と成熟葉, および古葉を用いた。こ こで ‘若葉’ は葉長 $4 \sim 5 \mathrm{~cm}$ の展開中の黄緑 色の葉を, ‘成熟葉’ は展開を終了して緑色と なった葉を，また ‘古葉’ は前回の萌芽期に展 開した暗緑色の葉を言う。

\section{2 葉組織の分離方法}

成熟葉からのプロトプラスト調製法)を参 考にして，以下の方法を標準的に用いた。醉 素液 $[1.5 \%(\mathrm{w} / \mathrm{v})$ マセロザイム R 10 (ヤク ルト), $0.1 \%$ ペクトリアーゼY S (盛進製薬), $0.5 \%$ キストラン硫酸カリウム, $10 \mathrm{mM}$ ア スコルビン酸ナトリウム, $10 \mathrm{mMMes}-$

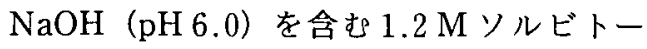
ル] $10 \mathrm{ml}$ に, 中肋と縁を苟刀で除いた葉約 $500 \mathrm{mg}$ を漫した。減圧して酤素液を組織内に 浸潤させた後, 室温で 1 時間 (若葉) 〜 10 時 間 (古葉) 静置した。先の鋭いピンセットで 上側と下側の表皮をはがし，さく状組織の細 胞は上側表皮から，また海綿状組織の細胞は 下側表皮と維管束組織から筆で静かに遊離さ せた。

これらの葉肉細胞は, $1000 \mathrm{rpm} て ゙ 2$ 分間遠 心分離して沈降させ, これを洗浄液（マセロ ザイムとペクトリアーゼを含まない酵素 液”）に懸濁させて再び遠心分離した。表皮組 織と維管束組織も洗浄液ですすいで酵素を除 いた。

\section{3 細胞数の計測と健全度の判定}

葉肉細胞は,血球計算盤を用いて計数した。 表皮細胞は, 顕微鏡下で一定面積当りの数を かぞえた。酵素処理に供した葉片の新鮮物重 量および葉面積から，単位重量または単位面 積当りの数に換算した。

遊離葉肉細胞のうち, 光学顕微鏡下で細胞 壁が完全に残り，かつクロロプラストが均一 に分布しているものを健全であると判定し た。なお，さく状組織細胞は，その長径／短

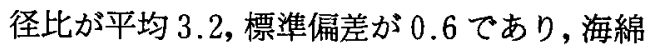
状組織細胞の值 $(1.3 \pm 0.2)$ とは全く異なっ ているため, 両者は容易に区別できた。

\section{4クロロフィル量の測定}

1 枚の葉を四分し,上下の各 $1 / 4$ の組織を 分離した。各分離組織と, 残り 1/2の末分離 葉組織をメ夕ノール中で磨砕し, 遠心上清の

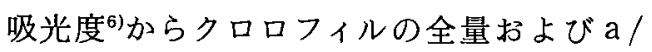
$\mathrm{b}$ 比を求めた。

\section{3. 結果}

\section{1 分離条件の検討}

組織の分離は 2 ，2 項に述べたように高浸 透圧下で行う必要があり，浸透圧調節物質を 添加しない場合には酵素液中に多数のクロロ プラストが認められた。浸透圧調節物質はり ルビトールのほかにグリセロールでも代替可 能であった。実験は葉内の浸透圧が高まる 12 月〜 1 月に主として行ったため $1.2 \mathrm{M}$ が適 当であったが，その後の検討により，4〜5 月には $0.8 \mathrm{M} て ゙ も$ 良好な結果が得られた。室 温で静置して酵素反応を行わせるかわりに $30^{\circ} \mathrm{C}$ で振とうすると, 反応時間を大幅に短縮 できる反面，葉の状態に応じた最適の時間を 厳密に調整しないと酵素液が褐変し, 青臭さ を生じた。

\section{2 分離組織の純度}

成熟葉から分離したさく状組織細胞の画分 （写真 1 A) には細長い細胞が多く, 海綿状 組織細胞の画分（写真 1 B) には不定形の細 胞が圧倒的に多かった。顕微鏡観察により, 大多数の細胞は健全と判断した。上側表皮(写 真 1 C) と下側表皮（写真 1 D）には，表皮 細胞数の $0.4 \sim 1.0 \%$ に相当する葉肉細胞が 付着していた。維管束組織を構成する維管束 鞘細胞と葉肉細胞を区別することはできな かったため，この画分への葉肉細胞の混入率 は不明である(写真 $1 \mathrm{E}$ )。有機酸塩と思われ る結晶を含有する細胞は, 維管束組織画分に 多かった。

3 枚の成熟葉から分離を行った結果（表 1), さく状組織細胞画分への海綿状組織細胞 の，また海綿状組織細胞画分へのさく状組織 細胞の混入率は 2 ～10\%であることが判明し 
た。若葉では, 両葉肉細胞画分への異細胞混 入率が $20 \sim 30 \%$ 程度と高く, また組織が軟弱 であるために手間がかかった。

次に分離した各組織の特徴をクロロフィル 含有量の面から検討した(表 2 )。未処理葉の クロロフィル量 $(\mathrm{mg} / \mathrm{g})$ は, さく状および海
綿状組織細胞画分中の量の合計值とほほ一致 したが, 表皮組織と維管束組織にもクロロ フィルは検出された。上側表皮組織の細胞に はクロロプラストが存在しないため, 葉肉細 胞がわずかに付着していることを示してい る。ただし, 表皮組織抽出液の可視部スペク
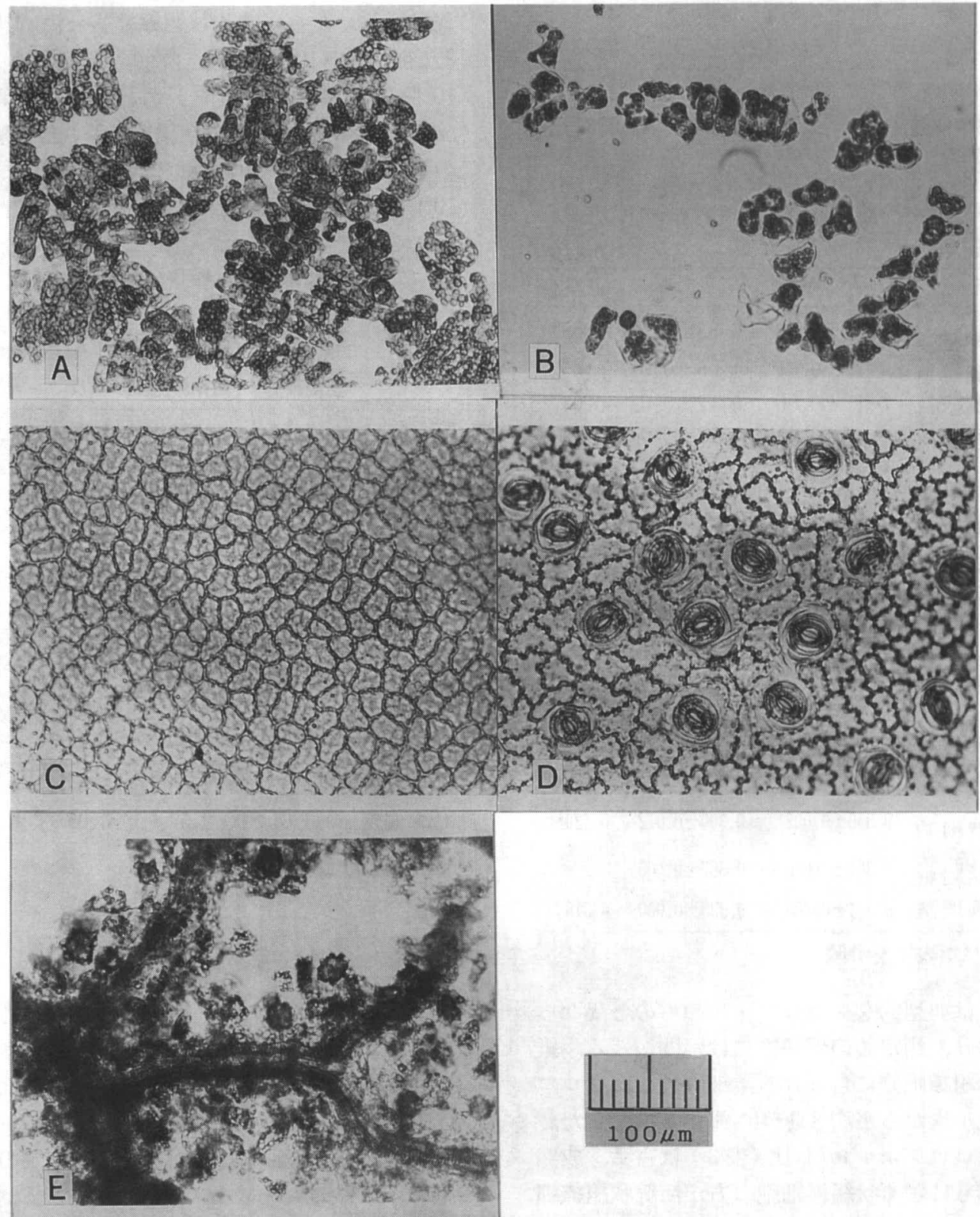

写真 1 チャの成熟葉から得たさく状組織細胞(A)，海綿状組織細胞(B)，上側表皮(C)，下側 表皮(D)及び維管束組織(E) 
表 1 分離したさく状細胞と海綿状細胞画分へ の他の細胞の混入率

\begin{tabular}{ccc}
\hline \multirow{2}{*}{ 実 験 } & \multicolumn{3}{c}{ 異細胞混入率 (\%) } \\
& $\begin{array}{c}\text { く 状 } \\
\text { 細胞 画 分 }\end{array}$ & $\begin{array}{c}\text { 海 } \\
\text { 細 胞 画 分 }\end{array}$ \\
\hline 1 & 6.2 & 3.6 \\
2 & 9.5 & 2.3 \\
3 & 4.3 & 3.3 \\
\hline 平均值 & 6.7 & 3.1 \\
標準偏差 & 2.2 & 0.6 \\
\hline
\end{tabular}

表 2 各分離組織のクロロフィルの含有量

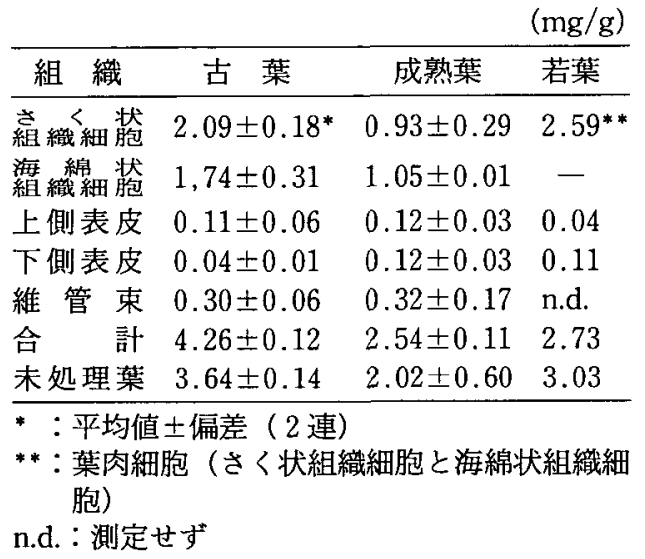

表 3 分離葉肉細胞のクロロフィル a $/ \mathrm{b}$ 比

\begin{tabular}{|c|c|c|c|}
\hline 組 織 & 古 葉 & 成熟葉 & 若葉 \\
\hline $\begin{array}{c}\stackrel{c}{<} \text { 状 } \\
\text { 組織細胞 }\end{array}$ & $0.355 \pm 0.002^{*}$ & $0.300 \pm 0.012$ & $0.320^{* *}$ \\
\hline $\begin{array}{l}\text { 海 綿 状 } \\
\text { 組織細胞 }\end{array}$ & $0.364 \pm 0.006$ & $0.367 \pm 0.005$ & - \\
\hline 末処理葉 & $0.314 \pm 0.006$ & $0.325 \pm 0.000$ & 0.315 \\
\hline
\end{tabular}

*,**：表 2 を参照

トルは典型的なクロロフィルのものと異なっ ており，測定值の信頼性には疑問が残る。維 管束組織画分に含まれる柔細胞数は，クロロ フィル量から平均 $8.1 \cdot 10^{6}$ 個 $/ \mathrm{g}$ と推定した。

クロロフィル a / b 比 (表 3 ) は古葉, 成熟 葉ともにさく状組織細胞の方が海綿状組織細 胞より小さく，細胞の形態だけでなくクロロ フィル組成の面からも葉肉細胞を 2 種に分離 できていることを示している。さく状組織細
胞にクロロフィル $\mathrm{b}$ が多いことは，光の利用 効率と関連していると考えられる。

\section{3 各分離組織に含まれる細胞数}

成熟葉の供試片（主脈と葉縁を除く） $1 \mathrm{~g}$ 当りに含まれる細胞数を分離組織ごとに計測 した（表 4)。10 枚の葉片について得た值（表 皮は 4 枚）から，さく状組織細胞と海綿状組 織細胞は $2 \cdot 10^{7}$ 個 $/ \mathrm{g}$ 強, 両側の表皮には 1 ・ $10^{7}$ 個 $/ g$ 前後存在することがわかった。葉 1 $\mathrm{cm}^{2}$ 当りのさく状, 海綿状組織細胞, 上下表皮 の平均細胞数は,それぞれ $3.5,4.2,1.8,1.7$ ・ $10^{5}$ 個と計算された。

表 4 成熟葉から分離した組織の細胞数

$\left(10^{7}\right.$ 個 $\left./ \mathrm{g}\right)$

\begin{tabular}{crccc}
\hline 実 験 & $\begin{array}{c}\text { さく状 } \\
\text { 組織細胞 }\end{array}$ & $\begin{array}{c}\text { 海綿状 } \\
\text { 織細胞 }\end{array}$ & $\begin{array}{c}\text { 上側 } \\
\text { 表皮 }\end{array}$ & $\begin{array}{c}\text { 下側 } \\
\text { 表皮 }\end{array}$ \\
\hline 1 & 1.55 & 1.63 & 1.03 & 1.16 \\
2 & 2.05 & 2.50 & 0.91 & 0.88 \\
3 & 1.87 & 2.89 & 1.14 & 0.93 \\
4 & 2.28 & n.d. & 0.97 & 0.82 \\
5 & 3.25 & 3.22 & n.d. & n.d. \\
6 & 2.28 & 3.37 & n.d. & n.d. \\
7 & 2.37 & 2.45 & n.d. & n.d. \\
8 & 3.46 & 2.91 & n.d. & n.d. \\
9 & 1.54 & 1.80 & n.d. & n.d. \\
10 & 2.58 & 2.94 & n.d. & n.d. \\
\hline 平 均 值 & 2.32 & 2.63 & 1.01 & 0.95 \\
標準偏差 & 0.61 & 0.57 & 0.08 & 0.13 \\
\hline
\end{tabular}

n.d.：測定せず

\section{4. 考察}

今回の実験に用いたチャは水耕栽培を行っ ており，野外に栽培されているチャに比べて 葉が薄く, 葉面積が大きい。それゆえ，面積 当りの葉肉細胞数は野外栽培のものより少な く,さく状組織細胞と海綿状組織細胞との構 成比も野外のものと異なっていると思われ る。形態観察とクロロフィル含有量から，分 離組織（細胞）はかなり完全な状態で得られ ていると考えられるが，生理的状態について 
はさらに検討を要する。

葉を構成する各組織の分離は, $\mathrm{C}_{4}$ 型光合成 植物における維管束鞘細胞の役割》)などの有 用な情報を提供してきた。チャ葉組織間でカ フェインやカテキン, アミノ酸, 糖などの成 分がどのように分布しているかを明らかにで きれば, 高品質の茶を生産するための栽培や 育種, および製茶工程の改善に役立つと思わ れる。著者らは，エピガロカテキンとエピカ テキンガレートが特に上側表皮に多いこと， アルギニンは維管束に, テアニンはさく状組 織細胞に多いことなどの予備的分析結果も得 ている。充分な検討を行った上で，これら成 分の測定結果を報告する予定である。

\section{5 . 摘 要}

チャの葉組織を構成する上下の表皮,さく 状組織細胞, 海綿状組織細胞と維管束とを以 下の手順で分離した：1）葉片をマセロザイ ムやペクトリアーゼ等を含む分離液に $1 \sim 10$ 時間（若い葉ほど，短時間）浸漬，2）上下 の表皮をピンセットではがす，3）さく状組 織細胞は上側表皮から筆で遊離させる，4） 同樣に, 海綿状組織細胞は下側表皮と維管束 から遊離させる。単離した組織（細胞）は形 態的に健全であった。上下の表皮, さく状お よび海綿状組織細胞は, それぞれ $1 \mathrm{~g}$ の葉片 あたり平均 $10,9.5,23 ， 26 \times 10^{6}$ 個含まれて いた。両葉肉細胞画分への異細胞混入率は 2 〜10\%だった。表皮組織には葉肉細胞はほと んど付着していなかった。維管束組織画分に
は平均 $8 \times 10^{6}$ 個 $/ \mathrm{g}$ の柔細胞が含まれると推 定した。

\section{6. 引用文 献}

1) Sanderson, G. W. (1972) : The chemistry of tea and tea manufacturing. In : Recent Adv. Phytochem., No. 5, ed. by V. C. Runeckles and T. C. Tso, Acad. Press, 247-316.

2) Takebe, I., Otsuki, Y. and Aoki, S (1968) : Isolation of tobacco mesophyll cells in intact and active state. Plant Cell Physiol., 9, 115-124

3 ) 青木 智 (1979) : 茶葉からの細胞単離と その光合成特性, 日作紀，48，343-349

4 ）久保井徹・須田ます代・寺尾玲子・小西 茂毅 (1991)：チャ葉プロトプラストの効 率的調製法，茶研報，№. 74，15-23

5 ）小西茂毅・宮本倉文（1984）：茶樹の生育 に対するアルミニウムの促進効果とその リン酸吸収特性, 土肥誌, 55, 29-35

6) Vishnic, W. (1957) : Methods for study of the Hill reaction. In: Methods in Enzymol., 4, 342-355

7 ) Edwards, G. E. and C. C. Black, Jr. (1971) : Isolation of mesophyll cells and bundle sheath cells from Digitaria sanguinalis (L.) Scop. leaves and a scanning microscopy study of the internal leaf cell morphology. Plant Physiol., 47, $149-156$ 